\title{
Royalty sharing, effort and invention in universities: evidence from Portugal and Spain
}

\author{
Pere Arqué-Castells ${ }^{*}$, Rui M Cartaxo ${ }^{\dagger}$, Jose García-Quevedo ${ }^{\ddagger}$ and Manuel \\ Mira Godinho ${ }^{\S}$
}

\begin{abstract}
Portuguese and Spanish universities have adopted well-defined royalty sharing schedules over the last fifteen years. We investigate whether such royalty sharing schedules have been effective in stimulating inventors' efforts and in ultimately improving university outcomes. We base our empirical analysis on university-level data and two new self-collected surveys for both inventors and Technology Transfer Offices (TTOs). Evidence from the inventors' survey indicates that one third of respondents are incentivised by current royalty sharing schedules, one third could be incentivised by higher royalty shares, and the remaining third is totally insensitive to royalty sharing. Plain regressions on university level datasets suggest that the incentive effects documented by the inventors' survey fail to translate into increased patenting or licensing income. It would seem that inventor royalty shares are not as influential as they could be, due to the poor commercial prospects of university inventions. Among other possible reasons, these poor prospects appear to reflect the fact that inventors are unable to produce potentially licensable inventions, or that eventually TTOs may not be focussing enough on commercialising their inventions.
\end{abstract}

Keywords: patents, IPR, university, knowledge transference

JEL codes: 034, 031, I23

\footnotetext{
" Searle Centre on Law, Regulation and Economic Growth (Northwestern University) and Barcelona Institute of Economics (IEB). e-mail: pere.arque@law.northwestern.edu

${ }^{\dagger}$ ISEG - Lisbon School of Economics and Management, Universidade de Lisboa, UECE - Research Unit on Complexity and Economics. e-mail: r.car@sapo.pt

* University of Barcelona (Department of Public Economics) and Barcelona Institute of Economics (IEB). e-mail: jgarciaq@ub.edu

$\S$ ISEG - Lisbon School of Economics and Management, Universidade de Lisboa and UECE - Research Unit on Complexity and Economics. e-mail: mgodinho@iseg.ulisboa.pt
} 


\section{Introduction}

It is well documented that the so-called third mission of universities, namely the transfer of knowledge to industry, has real effects on local economic development (Etzkowitz, 2002; Jaffe, 1989). Such knowledge transfer can be implemented via a number of routes, including the hiring of students, sponsored research, licensing, the creation of university spin-off firms, or simply via knowledge spillovers (Bercovitz and Feldman, 2006). In this regard, one mechanism that has become increasingly important for researchers and policymakers alike is patent licensing (Geuna and Rossi, 2011; Perkmann et al., 2013). ${ }^{1}$

A question that has aroused considerable interest of late is whether pecuniary incentives for inventors are a useful tool for improving licensing outcomes. In the US, as in most European countries, university intellectual property policies grant the university control of rights over inventions (Sampat et al., 2003; Geuna and Rossi, 2011). The income from royalties from inventions is then shared between the inventor and the university, according to terms that are generally specified by the university. This naturally allows (or even forces) universities to decide which pecuniary incentives, in the form of inventor royalty shares, are to be offered to inventors. If inventors care about potential royalties, then universities can conveniently set inventor royalty shares in such a way as to incentivise their effort.

The purpose of our paper is to investigate the role of inventor royalty shares in incentivising scientists' efforts, and to ultimately provide advice on how to improve university patenting and licensing in Portugal and Spain ${ }^{2}$. Both countries have been particularly active over the last few years in developing an appropriate infrastructure for improving knowledge transfer (Geuna and Rossi, 2011; Lissoni, 2013; Cartaxo and Godinho, 2014). Among the many measures taken, has been the adoption of well-

\footnotetext{
${ }^{1}$ Patenting and licensing are important components of university technology transfer and have been the focus of many studies over the last two decades. Verspagen (2006) surveyed the literature on university patenting, while Baldini (2006) provided a review of the literature on patenting and licensing in universities.

${ }^{2}$ While license income is the main outcome of interest, patents are also useful in the context of this paper. Patents are an intermediate input for the generation of license revenues (inventions are patented, and then commercialised). It is precisely because patents come first that they might react with a shorter lag to variations in royalty sharing. Being able to capture early effects is important in countries such as Portugal and Spain, where royalty sharing splits have been set relatively recently. Furthermore, TTOs in both Portugal and Spain seem to be using royalty sharing to increase patenting.
} 
defined royalty sharing schedules by universities. Are such royalty sharing schedules producing the expected effects? The studies to date have presented mixed results regarding whether such royalty sharing arrangements are effective in incentivising academics' efforts, suggesting that they might be persuasive in certain institutional contexts, but not in others. Portugal and Spain have specific characteristics that make them an interesting case. Firstly, university patenting and licensing are recent phenomena, which remain at a low rate. Secondly, Technology Transfer Offices (TTOs) are relatively young, and are still in an early stage of their learning curve. Thirdly, the quality of applied research might not be as high as that in the US.

We build on the analytical framework proposed by Lach and Schankerman (2008) to understand the conditions that govern whether inventor royalty shares are likely to be effective. Intuitively, higher inventor royalty shares increase the premium for obtaining licensable inventions. Scientists are expected to react to this premium by increasing their effort in applied research. However, this incentive effect could be diminished if the revenues to be shared between the inventor and the university were trivial. Such a scenario with trivial royalties could arise if, among other reasons, TTOs were ineffective at commercialising good inventions, or if inventors were unable to produce inventions with good commercial prospects.

Within this framework, we seek to answer two research questions. First, are inventor royalty shares effective in stimulating inventors' efforts and in improving university outcomes? Second, are incentive effects diminished because TTOs are ineffective at commercialising inventions, and/or inventors are not good enough at generating licensable inventions? In order to empirically answer these research questions we employ a mix of objective evidence from university-level data and also subjective evidence from new self-collected surveys of TTOs and inventors.

Our paper is related to a vast conceptual and empirical literature that aims to understand the motives of academic patenting (Stephan, 1996; Lam, 2011). This literature has generally found university inventors to be more strongly motivated by traditional reputational and career rewards, rather than by pecuniary incentives. Instead of attempting to assess the relative value of the many potentially important motivations of 
academic patenting, we carry out an in-depth analysis of one such motivation: royalty sharing.

Our paper is therefore most closely related to the empirical literature concerned with estimating the effectiveness of royalty sharing. ${ }^{3}$ The papers in this literature typically rely either on university-level, or inventor-level datasets. Quite intriguingly, the former documents incentive effects, while the latter fail to identify these effects. Two of the papers that found positive incentive effects using university level data are those of Baldini (2010) and Caldera and Debande (2010). Like us, they too focus on low licensing income countries. Our paper however differentiates from theirs and from most of the remaining papers in the literature in two important ways.

First, instead of relying just on university or inventor data, we use both. This enables us to not only infer incentive effects indirectly, by regressing university outcomes on royalty shares, but also to do so in a more direct way, by explicitly asking inventors about the effectiveness of royalty shares. To the best of our knowledge, no one has ever done so before. Testing for incentive effects with inventor level data is important in countries such as Portugal and Spain, where royalty sharing schedules have been set relatively recently, and these might have produced incentive effects that have not yet translated into increased patenting and licensing. Additionally, inventor-level data enables us to understand some of the subtleties that go undetected with university-level data alone. For instance, we can infer the percentage of inventors that is already incentivised by royalty sharing, that which could be potentially incentivised by higher inventor royalty shares, and that which is totally insensitive to royalty sharing. The middle group is a potentially interesting target for decision makers.

Second, we not only study the presence or absence of an incentive effect, but also whether the conditions necessary for this effect to exist hold. While previous papers have studied whether incentive effects are diminished by TTOs' ineffectiveness at commercialising inventions (see Lach and Schankerman, 2008; Belenzon and Schankerman, 2009), we are the first to empirically test whether incentive effects are also diminished by inventors' ability to produce licensable inventions. Admittedly, due

\footnotetext{
${ }^{3}$ This literature is exhaustively surveyed in Table 1, in Section 2.2.
} 
to limitations in our data, we are only able to provide tentative evidence of the existence of these two potentially important effects.

We obtain three main findings. Firstly, the inventor surveys reveal that one third of inventors are incentivised by current royalty sharing schedules (although only a few find royalty sharing to be highly influential), one third could be potentially incentivised by royalty sharing (if royalty shares were increased, or if scientists have better information about royalty sharing), and the remaining third is totally insensitive to royalty sharing. Secondly, plain regressions on university level datasets suggest that the incentive effects documented by the inventors' surveys fail to translate into increased patenting, or licensing income. Thirdly, both the gatekeeper and ability effects seem to diminish royalty sharing incentive effects.

The paper is structured as follows. Section 2 presents the analytical setting and derives the research questions of interest. Section 3 offers a review of the institutional context in Portugal and Spain, and describes the datasets used in the empirical analysis. Section 4 empirically answers the research questions posed in Section 2. Section 5 concludes.

\section{Analytical setting and research questions}

In the traditional "Mertonian" world of scientific discovery, the main goal of scientists is to establish their priority of discovery by being the first to communicate an advance in knowledge. Accordingly, most scientists seem to be motivated by the traditional reputational and career rewards that are provided by the scientific community which come in the form of eponymy, prizes and publication (Stephan, 1996; Lam, 2011). In line with this traditional view, some studies conclude that reputation lies at the heart of scientists' decision to patent. ${ }^{4}$

While it is widely argued that academics respond to non-pecuniary incentives, recent research has sought to determine the extent to which pecuniary incentives also matter. Pecuniary incentives are of interest to policymakers as they can be used as a potentially effective means of involving scientists, not just in discovery, but also in the transfer of the knowledge generated beyond the boundaries of academia (Markman, 2004).

\footnotetext{
${ }^{4}$ See Bodas Freitas and Nuvolari (2012), Göktepe-Hulten and Mahagaonkar (2010), Baldini et al. (2007) and Owen-Smith and Powell (2003).
} 
In this paper we seek to study the effects of a very specific form of pecuniary incentive: the share of royalty income apportioned to university scientists. Higher inventor royalty shares secure higher returns for applied research activities that are conducive for licensable inventions. Do inventors react to such incentives? Can universities improve their technology transfer outcomes by conveniently setting their royalty sharing schedules? In what follows, we build on Lach and Schankerman (2008) to understand how, and under which conditions, royalty sharing stimulates inventors' effort.

\subsection{Analytical setting}

Basic setup - Lach and Schankerman (2008) develop a simple model that captures the dual purpose of scientific research. Scientists derive utility from both scientific publications and license revenue..$^{5}$ Publications can be obtained through basic and applied research, whereas license revenue can only be obtained through applied research. ${ }^{6}$ The distinction between basic and applied research imposes a tradeoff between the two through the allocation of effort. Policymakers therefore try to shift effort from basic to applied research, by making the latter relatively more attractive.

A natural way of increasing the premium of applied research effort in countries under an institutional ownership regime -where universities retain control rights over inventions, but share the licensing income with the inventor- is by apportioning a larger share of royalty income to scientists. Lach and Schankerman (2008) show that, under fairly general conditions, scientists' optimal applied research effort - and in turn the license revenue resulting from this optimal applied research effort - is increasing in the inventor royalty share. ${ }^{7}$

\footnotetext{
${ }^{5}$ Note that publications might prove useful not only through increased reputation, but also in the form of monetary rewards from tenure, or wage increases that come with promotions.

${ }^{6}$ Lach and Schankerman (2008) distinguish between two types of applied research: applied research devoted to starting new projects, and applied research aimed at improving the quality of each project. For expositional clarity we will just refer to applied research.

${ }^{7}$ This result holds if the diminishing returns to income in the scientist's utility function are not "too strong". If there is complementarity between basic and applied research efforts, then the results also apply to basic research. Lach and Schankerman (2008) show that optimal applied research effort is also increasing in the TTO's effectiveness at commercialising inventions. We abstract from this second result.
} 
Interaction effects - The extent to which scientists react to variations in royalty sharing critically depends on two policy parameters: TTO's effectiveness at commercialising inventions, and scientist's ability to conduct applied research. ${ }^{8}$

Regarding the first of these policy parameters, increases in inventor royalty share will have smaller effects if scientists anticipate that TTOs will do a poor job at commercialising their inventions. In the extreme case of a totally incompetent TTO, the inventor royalty share will not matter at all. Lach and Schankerman (2008) call this interaction between the incentive effect of the inventor royalty share and the effectiveness of the TTO the gatekeeper effect.

Regarding the second policy parameter, increases in inventor royalty share will have smaller effects if scientists anticipate that, given their applied research skills, their inventions will have little commercial success. Scientists will not care about royalty sharing at all in the limiting case, where their ability to conduct applied research is so low that not even the maximum effort will raise the quality of their inventions above the minimum standards required for commercialisation by the TTO. We call this interaction between the incentive effect of the inventor royalty share and the ability of the inventor to conduct applied research the ability effect. $^{9}$

Research questions - According to the theoretical predictions in Lach and Schankerman (2008), inventor royalty shares should be effective at triggering incentive effects. It is this effectiveness that we seek to test empirically. Besides testing for the presence of incentive effects, we are also interested in learning the extent to which these effects are diminished by the gatekeeper and ability effects. Our research questions of interest can be formalised as follows:

\footnotetext{
${ }^{8}$ When we mention "ability to conduct applied research", we indeed refer to the capacity to undertake applied research that can subsequently be exploited economically by patenting and licensing. We could also have used the terms "ability to do relevant or commercially oriented applied research".

${ }^{9}$ The ability effect is not explicitly taken into account in Lach and Schankerman (2008), who assume scientists to have a sufficiently high level of ability to generate inventions that will be licensed by a TTO with some probability. We seek to consider an additional scenario, in which less-able scientists produce inventions with no probability of being licensed by a TTO. The ability parameter can be accommodated within Lach and Schankerman's (2008) setting as an interaction with TTOs' effectiveness at commercialising inventions. This implies that license revenue can be diminished, either because the TTO is not good at commercialising ideas, or because the inventor is less capable of conducting marketable applied research.
} 
1. Are inventor royalty shares in Portugal and Spain effective in stimulating inventors' efforts and in improving university outcomes?

2. Are royalty share incentive effects diminished because TTOs are not pursuing invention commercialisation with the necessary intensity, and/or inventors are bad at generating licensable inventions?

\subsection{Literature review}

All the empirical studies that set themselves the objective of answering the first research question are summarised in Table 1. We have split the articles, based on two dimensions: unit of analysis (university vs. inventor), and type of country (high licensing income vs. low licensing income). This division helps identify two somewhat conflicting regularities in the literature. First, papers that use universities as the unit of analysis are unanimous in finding positive incentive effects, as revealed by the sensitivity of licensing income (not so much the number of licenses) to variations in royalty shares. Interestingly, this positive incentive effect is present in both high (Group A) and low (Group B) licensing income countries. This is puzzling, as the latter group of countries - where universities are public and less proactive at recruiting talented researchers - should be more exposed to the gatekeeper and ability effects and, consequently, less fit for incentive effects. Second, papers using inventors as the unit of analysis are equally unanimous in failing to document positive incentive effects of royalty shares. Rather, they tend to find reputation to be a much more important determinant of involvement in disclosure and patenting. Again, the absence of incentive effects in papers based on inventor surveys holds for both high (Group C) and low (Group D) licensing countries.

The set of papers that has sought to study our second research question - which contextual factors make royalty shares an effective pecuniary incentive? - is smaller. Lach and Schankerman (2008) find royalty shares to be more effective in private universities, which they show to be more pro-active than public universities at commercialising inventions. Similarly, Belenzon and Schankerman (2009) find royalty shares to be substantially more effective in universities with TTOs governed by 
incentive pay systems. Both results can be taken as evidence that the gatekeeper effect matters. Walter et al. (2013) find that the extent to which financial incentives are effective at stimulating the inventor's propensity to disclose inventions depends on inventor characteristics, such as academic field, or patenting experience. This result suggests that the ability effect matters too, with higher ability (at producing licensable inventions) scientists being more responsive to pecuniary incentives.

\section{[INSERT TABLE 1]}

\section{Institutional setting and data}

\subsection{Contextual setting}

Institutional ownership - The Portuguese intellectual property law (Código da Propriedade Industrial) has no specific reference to university intellectual property. Universities have traditionally been the sole proprietors of the inventions generated by their faculty, with statutory legislation not foreseeing the participation of faculty in licensing revenues. The first explicit university-specific intellectual property rights policy with well-delimited inventor royalty shares was not adopted until 1998, at the Instituto Superior Técnico. Similar statues were gradually adopted over the following decade, with the vast majority of universities operating well-defined royalty sharing schemes today. ${ }^{10}$

Spain was one of the first European countries, together with the United Kingdom and Switzerland, to adopt the institutional ownership system (Azagra-Caro, 2011; Geuna and Rossi, 2011). The framework for scientific and patenting activities has been well defined since the 1980s, which was when the University Reform Law allowed university researchers to receive income from contracts with firms, including arrangements that led to patents and licensing (Azagra-Caro, 2011). ${ }^{11}$

\footnotetext{
${ }^{10}$ The University of Coimbra adopted explicit intellectual property right norms in 2003, and several other universities did so between 2005 and 2011.

${ }^{11}$ In particular, the Spanish Law of Patents (Law 11/1986 of Patents of Inventions and Utility Models) gives both universities and researchers an incentive to patent the results of their research.
} 
TTOs - Both in Portugal and Spain, the different phases of university patenting, ranging from disclosure of inventions to licensing, are managed by Technology Transfer Offices (TTOs).

In Portugal, two different types of TTO have coexisted until recently: GAPIs and OTICs. The former could be found in universities, technology centres, and business associations, while the latter were only active in academic institutions (see Cartaxo and Godinho, 2014). Most of the TTOs were created after 2000, usually employing no more than two or three staff. GAPIs and OTICs have recently evolved to a single structure in each university. ${ }^{12}$

In Spain, TTOs go by the name of OTRIs (Offices for the Transfer of Research Results), and all public universities have one. OTRIs are responsible for the transfer of university research through a variety of forms, including spin-off creation, R\&D projects, patenting and licensing. The first OTRIs were created in 1988, via a public policy initiative aimed at promoting co-operation between universities and industry. ${ }^{13}$ OTRIs acquired an official character in 1996, and organised themselves into a network (known as RedOTRI) in 1997. The number of OTRIs grew substantially after these two events.

Royalty sharing schedules - Almost all universities in Portugal and Spain have their own regulations for the split of licensing income. The schedules are freely chosen by each university, and have to be approved by their respective management bodies. Income is generally allocated either to universities or researchers, but on occasions it can also be shared with the inventor's department or research group. The royalty shares in force in each university are reported in the corresponding intellectual property rights rules of the university. Changes in their values have to be duly notified through changes

\footnotetext{
${ }^{12}$ GAPIs were created by the Portuguese Patent and Trademark Office (INPI) as from 2000, with the aim of promoting the use of intellectual property. OTICs were established as from 2006 by the Innovation Agency (AdI). Some GAPIs and OTICs were based on previously existing extension offices. In such instances, technology licensing and transfer activities coexist with other tasks (such as mentorship to spinoffs, training, or research management). These TTOs tend to employ a larger number of staff, but the figure of no more than two or three technicians engaged in technology transfer remains valid for most universities.

${ }^{13}$ The 1986 Law for the Promotion and General Coordination of Scientific and Technological Research (the "Science Law"), which emphasised the need to promote collaboration in R\&D between firms and universities, established the foundations for the creation of the first OTRIs.
} 
in the intellectual property right statutes. As we explain in more detail below, inventor royalty shares tend to concentrate at around 50\%, and most universities specified their royalty sharing schedules after 2000 (95\% in Portugal and 73\% in Spain).

Patenting and licensing trends - University patenting is a recent, albeit increasing, phenomenon in both countries. In Portugal, the first university patent was not awarded until 1998, and the cumulative number of university patents did not reach double figures until 2001. This late take-up in university patenting can partially be accounted for by the failure of the intellectual property law to explicitly define norms with regard to university patenting. Despite the late start, the share of university patents in Portugal (over the total number of patents in the country) rose from almost zero in 2000, to more than one third in 2009. The only data available on licensing income from Portugal is that collected through our survey of TTOs. Only four universities are found to report positive licensing income, and the first royalties were not obtained until 2008. This suggests that university licensing is still in its infancy in Portugal.

University patenting in Spain was not frequent until the 1990s. Since this date, the number of university-owned patents has experienced continuous growth, with the number of university patent applications (in the national patent office) rising from 210 in 2000, to 496 in 2012. At present, patents awarded to universities account for almost $15 \%$ of all patents granted (almost twice the share in 2000). Although the distribution of patents is strongly skewed, with some universities being particularly active, patenting is not restricted to a specific group of universities, and almost all public universities consistently apply for at least one patent per year. Total licensing income (from patented and non-patented technologies) has experienced a similar trend, rising from $€ 0.5$ million in 2000 , to $€ 2.5$ million in 2011 . $^{14}$

\subsection{Data}

In order to study the impact of inventor royalty shares on university technology transfer outcomes, we use three self-constructed datasets for each country: a university-level dataset, a survey addressed to all Portuguese and Spanish university TTOs, and another

\footnotetext{
${ }^{14}$ Licensing income from patents seems to account for slightly more than one half of total licensing income in Spain.
} 
survey of a representative sample of inventors in Portugal and Spain. Each dataset is described below.

University-level dataset - This is an unbalanced panel, spanning the years of 2007 to 2011 (both inclusive) for 15 Portuguese and 39 Spanish universities. ${ }^{15}$ The sampling criterion was to retain all university-years for which all the following variables could be observed: inventor royalty shares, the number of patent applications made at the respective national offices, licensing income, size and age of the TTOs, faculty size, the volume of R\&D expenditure (only for Spain), and presence of a science park. ${ }^{16}$ Most of the instances in which we had to discard a university-year were on account of the lack of information on outcomes (patents or licensing) or the explanatory variable of interest (inventor royalty share). Tables 2 and 3 provide descriptive statistics and definitions for each of these variables.

\section{[INSERT TABLES 2 AND 3]}

The main outcomes of interest (licensing income and number of patent applications) take rather low values, and their distribution is highly skewed across universities. Licensing income in Portugal ranges from a minimum of zero, to a maximum of $€ 274,000$. Average licensing income is slightly above $€ 10,000$ per year, but the median is indeed zero. Licensing income in Spain ranges from a minimum of zero, to a maximum of $€ 600,000$. Average licensing income is slightly above $€ 60,000$ per year, but the median is much lower at $€ 29,600$. The average number of annual patent applications is around 10 for both Portugal and Spain. This number is also unevenly distributed across universities, with the minimum and maximum values ranging from 0 to 54 in Portugal, and 0 to 72 in Spain. The median number of patent applications is slightly below the mean (7.5 in Portugal, and 9 in Spain). ${ }^{17}$

\footnotetext{
${ }^{15}$ We restrict the panel to the period post-2007, as inventor royalty share schedules had not been defined in several Portuguese universities before this date.

${ }^{16}$ The university-level dataset for Portugal contains information on 15 universities, which account for $97 \%$ of university patent applications in the period 2005-2012. The university-level dataset for Spain includes information on 39 universities, which represent $83 \%$ of the universities holding at least one patent, and $89 \%$ with positive licensing income in the 2010 Red-OTRI Survey.

${ }^{17}$ Notice that these numbers are extremely low when compared to the income generated in the US. According to Lach and Schankerman (2008), US universities generated, on average, \$3.6 (€3) million of license income per year during the 1990s, with the top $10 \%$ private universities earning, on average, over $\$ 11.5(€ 10)$ million per year (almost five times more than all the Spanish and Portuguese universities together).
} 
Inventor royalty shares in Portugal and Spain present similar patterns. Figure 1 plots the distribution of royalty shares, with average and median values standing at around $55 \%$ in both countries. Most universities opt to fix inventor royalty share at between $50 \%$ and $60 \%$, with only a few universities opting for extremely low (around 30\%), or high (above $70 \%$ ) royalty shares for inventors.

\section{[INSERT FIGURE 1]}

TTO survey - The main objective of the survey for TTOs was to obtain the exact inventor royalty share at each university, the year in which royalty shares were first introduced, and whether the shares have experienced significant changes over time. We were also interested in understanding the administrative process by which royalty sharing schedules were approved at each university, and also the goals each university pursued with its specified royalty share. The survey was sent to all Portuguese and Spanish TTOs during 2011. The response rate was highly satisfactory. All Portuguese TTOs (i.e., 22 TTOs) filled in the survey between June 2011 and April 2012, and 47 Spanish TTOs did so between January 2011 and December 2012 (an 89\% response rate). ${ }^{18}$

Inventors' survey - The primary goal of the survey was to obtain direct feedback from university inventors on the importance of inventor royalty shares. A second goal of the survey was to relate the effectiveness of royalty shares in measuring inventor quality.

The target of the survey was all those Portuguese and Spanish inventors that had applied for at least one patent between the years 2005 and 2009 (both inclusive) at USPTO, EPO, or one of their respective national offices (INPI in Portugal, and OEPM in Spain). In order to approximate this target population as closely as possible, we first retained all the patent applications (to the aforementioned offices) for which the assignee was a Portuguese (555 patent applications), or Spanish (5,148 patent applications) university.

\footnotetext{
${ }^{18}$ Red-OTRI (the network of Spanish TTOs) included 87 members in its 2010 directory. Most of these were ascribed to a university, but some were universities without a TTO, or TTOs ascribed to centres other than universities (such as scientific institutes and research centres). Most of the scientific research, and virtually all the patents and license income is generated by 53 public universities. Therefore, we sent the survey to the TTOs of those universities that constitute our relevant population ( 47 of which filled it out).
} 
19 We then located the email addresses of the inventors of these patent applications through personalised Google searches. This yielded 534 email addresses in Portugal, and 3,033 in Spain (after dealing with multi-applicant inventors). We invited all the university inventors for whom we had an email address to answer an online survey in January (Portugal) and November (Spain) 2012. From this we obtained 212 complete responses for Portugal, and 606 for Spain (equating to $40 \%$ and $20 \%$ response rates, respectively).

We asked inventors to supply their individual characteristics (field of research, age, gender, type of contract with the university, rank and measures of quality), and also their opinion on several aspects relating to the effectiveness of royalty shares. Table 4 reports the descriptive statistics of the inventor characteristics. The results of the inventors' perceptions of the royalty shares are discussed in the next section.

\section{[INSERT TABLE 4]}

\section{Evidence}

We seek to provide empirical answers below to the two research questions posed in Section 2. We first study whether inventor royalty shares are effective at stimulating inventors' efforts. Next, we analyze whether incentive effects are likely to be diminished by the gatekeeper or ability effects.

\subsection{Do inventor royalty shares have an incentive effect?}

In order to answer this question, we rely on both university and inventor level data. University level data allows for an indirect, ex-post analysis of incentive effects. We say indirect, as we do not directly test for an increase in inventors' effort (which is unobservable), but rather in the results of this effort, namely patenting or licensing income. Ex-post is specified, as the incentive effect must have taken place and be translated into an increase in university outcomes for it to be traceable by the econometrician. Inventor level data allows for a more direct, but not necessarily ex-post analysis, which allows for detecting the existence of incentive effects, even when these

\footnotetext{
${ }^{19}$ Even though we began gathering patent application data from around 2010-2011, we could only collect data on applications filed up to 2009 , due to the 18 months lag between application and pre-grant publication.
} 
have not translated into increased outcomes. This is important in countries, such as Portugal and Spain, where royalty sharing schedules have been set relatively recently, and might have produced incentive effects that have not yet translated into increased patenting and licensing.

\subsubsection{Evidence from university-level data}

We adopt the empirical specification put forward by Lach and Schankerman (2008), which results from scaling up the scientist license revenue or number of applied research projects - both shown to depend on inventor royalty share - to the university level. ${ }^{20}$ Taking logs, and linearising the university revenue or total number of projects yields, the following empirical equation is applied:

$$
y_{i t}=\delta \text { inventor royalty } \text { share }_{i t}+x_{i t} \beta+u_{i t}
$$

where $i$ indexes universities, and $t$ years. The dependent variable $y_{i t}$ stands for either (the log of) university licensing income, or (the log of) the number of university patent applications (our proxy for the number of applied research projects). The matrix of controls $x_{i t}$ includes (the $\log$ of) faculty size, proxies for the TTO's effectiveness at commercialising inventions, such as the size and age of the TTO; proxies for the inventors' average quality at doing applied research, such as R\&D per faculty, and; a dummy variable with a value of one if the university has a science park to capture the existing links between the university and private companies located nearby. Finally, we also rely on pre-sample information on patenting by universities to control for timeinvariant unobserved heterogeneity. The parameter of interest is $\delta$, which captures the effect of the inventor royalty share on the corresponding dependent variable. Positive values of $\delta$ imply that inventor royalty shares are effective at stimulating inventors' efforts.

\footnotetext{
${ }^{20}$ Lach and Schankerman (2008) show that scientists' revenue is increasing from their research effort. In turn, scientists' optimal research effort is increasing in the inventor royalty share. Therefore, scientists' revenue is also increasing in the inventor royalty share. Licensing revenue can be scaled up to the university level by multiplying the scientist revenue by faculty size.
} 
Lach and Schankerman (2008) highlight two sources of unobserved heterogeneity that are likely to be correlated with inventor royalty share. Firstly, researchers with greater commercial orientation or more valuable inventions may be able to lobby their universities for more favorable royalty shares (a reverse causality problem). This does not seem to be the case at Portuguese and Spanish universities, according to the survey for TTOs. ${ }^{21}$ Secondly, higher inventor royalty shares may attract more innovationoriented faculty (a sorting problem). ${ }^{22}$ Unlike in the US, the sorting channel is likely to play a minor role at Portuguese and Spanish universities, where faculty mobility is relatively low.

Although most universities are observed over several years, we are unable to use within estimators, as the royalty share displays little variation over time. ${ }^{23}$ Thus, the incentive effect of the royalty share is identified from the cross-sectional variation in the data. We follow the common approach of using pre-sample information on patenting to control for unobserved heterogeneity. We use clustered-robust standard errors to allow for heteroscedasticity, and autocorrelation within universities. Note that our specification is almost identical to the one used by Lach and Schankerman (2008), and very similar to that of related papers, such as that of Caldera and Debande (2010).

Table 5 shows equation (1) estimates based on the unbalanced panels of Portuguese and Spanish universities, as described in Table $1 .{ }^{24}$ For each country and dependent variable, we begin with a parsimonious specification that only includes royalty share, pre-sample information on patenting by universities, and time dummies (columns 1, 3, 5 and 7). The coefficient associated with the inventor's royalty share is only found to be

\footnotetext{
${ }^{21}$ The TTO survey suggests that inventors play a marginal role in the fixing of royalty shares, both at Portuguese and Spanish universities. Royalty share was a unilateral proposal from the Governing Council in $41 \%$ and $64 \%$ of Portuguese and Spanish universities, respectively, with no participation of the researchers. In about a third of the universities in both countries, royalty share was discussed in the Research Commission, with researchers being given the opportunity to influence the final decision. Only in $32 \%$ of Portuguese, and $2 \%$ of Spanish universities did the researchers play a more active role in royalty share decision.

${ }^{22}$ In this case, the estimated $\delta$ would be an upward biased estimate of the pure effort component of the royalty shares, but it would remain a consistent estimate of the overall incentive effect (including both the effort and sorting components).

${ }^{23}$ Only $14 \%$ of Portuguese TTOs, and $20 \%$ of the Spanish TTOs surveyed claimed to have changed the royalty shares over time. However, only four of these changes took place during the sample years selected for the econometric analysis in Spain, and three in Portugal.

${ }^{24}$ These panels only include universities for which all the relevant explanatory variables were available at some point in time (15 Portuguese, and 39 Spanish universities). We experimented with a simpler specification, with fewer explanatory variables (royalty shares, pre-sample patenting and time dummies) which allowed for broader panels, but the results remained unchanged.
} 
significantly different from zero, though at a $10 \%$ level, in column (3). Next we expand this specification with the explanatory variables discussed above (columns 2, 4, 6 and 8). The coefficient associated with inventor's royalty share is insignificantly different from zero in all cases, except in Column (6), where it is only significant at the $10 \%$ level. This set of results suggests that royalty shares play a negligible role in stimulating patenting and license income at university level in Portugal and Spain. As for the other regressors, the pre-sample average number of patent applications is significant in most of the regressions. This implies that this variable controls, at least in part, unobserved heterogeneity. The remaining explanatory variables are mainly insignificant. The amount of experience accumulated by the TTO seems to positively affect patenting in Portugal, while faculty size and R\&D intensity is positively correlated with patenting in Spain.

Somewhat surprisingly, our results do not agree with those obtained by Caldera and Debande (2010), who find license revenue to be positively affected by inventor royalty shares in Spain. This discrepancy is entirely driven by two universities, which introduced substantial changes in their royalty sharing schedules between the periods 2001-2005 (the period analysed by Caldera and Debande, 2010), and 2007-2011 (the period analysed in our paper). ${ }^{25}$ When we drop these two universities from the sample, we can indeed replicate Caldera and Debande's (2010) results (see Table 1A in the Appendix). Our interpretation of the reversal of Caldera and Debande's (2010) results goes as follows - the change in the royalty sharing schedules of two universities add within variation in the data, and, whereas the inventor royalty rates in these two universities increased very drastically, their patenting and licensing outcomes did not. As a result, the incentive effect becomes insignificant.

\section{[INSERT TABLE 5]}

\subsubsection{Evidence from inventor-level data}

Direct feedback from the inventors' survey is reported in Table 6. Inventors seem to be strikingly unaware of the royalty shares in force at their universities (see Question 1).

\footnotetext{
${ }^{25}$ These two universities are the University of Cádiz, and the University of Extremadura. The first raised the inventor royalty share from $50 \%$ to $90 \%$ in 2007 . The second one defined its royalty sharing schedule in 2005 , with a very generous $80 \%$ inventor royalty share.
} 
However, most of the inventors who are aware of royalty share values claim to be incentivised by royalty sharing, with a relatively small percentage of inventors being highly influenced by royalty sharing (see question 2). Interestingly, most of the inventors who are either unaware of the royalties, or who are aware of them, but are not influenced by the current royalty schedules, state that there is a minimum inventor royalty share threshold that would trigger their effort (see question 3). Surprisingly, the average value of this threshold is below the average value of the inventor royalty shares in force (see question 4$){ }^{26}$

\section{[INSERT TABLE 6]}

Figure 2 splits the respondents, based on whether they are sensitive, or not, to royalty sharing, and on whether they are incentivised, or not, by the royalty sharing schemes in force. Around 33\% of the respondents in Portugal and Spain are totally insensitive to royalty sharing, meaning that they would not increase their effort for any value of inventor royalty shares, whereas the remaining $67 \%$ of inventors is sensitive to royalty sharing. Regarding this last group, 33\% (19\%) of inventors in Portugal (Spain) are already incentivised by royalty sharing, with royalties having a varying degree of importance for them. Importantly, 34\% (48\%) of the sensitive inventors in Portugal (Spain) are not incentivised by royalty sharing at present, but would be for higher inventor royalty shares. The vast majority of the inventors in this last group is unaware of the current royalty sharing schedules. This means that TTOs could perhaps achieve better outcomes by providing updated information to scientists on the current inventor royalty share values. ${ }^{27}$

\section{[INSERT FIGURE 2]}

The results in this section are interesting for three reasons. Firstly, the fact that incentive effects arise for only about one third of respondents means that most inventors are

\footnotetext{
${ }^{26}$ This last point is entirely driven by 'unaware' inventors, who set the "effort" threshold lower than the threshold set by 'aware' (but uninfluenced) inventors.

${ }^{27}$ Notice that many of the inventors in the last group (i.e. could be incentivised, but are uninformed) provide effort thresholds (royalty thresholds above which it would be worthwhile to increase their effort) below the royalty shares in force at their universities (see Table 6, row 4.3). This reinforces the perception that improved information practices about royalty sharing could be particularly effective.
} 
driven by motives other than royalty sharing when engaging in patenting activities. ${ }^{28}$ Secondly, inventor-level data reveals that royalty sharing does incentivise the effort of some researchers, while university-level data suggests that this incentivised effort fails to translate into increased patenting, or licensing (at least in Portugal). Thirdly, the finding that a relatively small percentage of inventors are incentivised by royalty sharing helps explain the discrepancy in the results obtained by papers using university vs. inventor level data: inventor-level studies, which tend to average over inventors, find no incentive effects, as the average inventor is indeed not motivated by royalty sharing; however, the effort triggered in the few incentivised inventors might result in increased licensing revenue for the university (though this university level effect is not robust in our paper).

\subsection{Could the current royalty sharing schedules be more effective?}

Figure 2 shows that most inventors are sensitive to royalty sharing. However, only a few of these sensitive inventors find royalty sharing to be highly influential. Why do royalty shares matter relatively little for those inventors who are sensitive to them? Below, we discuss the extent to which the gatekeeper or the ability effects might be diminishing the incentive effects of royalty shares.

TTOs' gatekeeper effect - As in most European countries, Spanish and Portuguese universities retain ownership of intellectual property rights, with the commercialisation of inventions depending ultimately on TTOs. This means that inventors' licensing revenues are largely dependent on the ability of TTOs to find licensees and to negotiate agreements. As discussed in the analytical setting, a possible reason for royalty shares having a smaller incentive effect, or no effect at all, is that the TTO is not pursuing invention commercialisation with the necessary intensity. Does the TTOs' inability to successfully commercialise inventions account for the ineffectiveness of royalty shares?

A formal method of empirically testing for the gatekeeper effect in the US has involved exploiting the fact that private universities are more aggressive than their public

\footnotetext{
${ }^{28}$ Several papers find reputation to be the main motive for scientist's involvement in patenting (e.g. Göktepe-Hulten and Mahagaonkar, 2010; Baldini et al. 2007). Scientists might also be able to commercially exploit patents without necessarily licensing them (i.e. through spin-off creation, or R\&D contracts).
} 
counterparts in their licensing strategies. ${ }^{29}$ This strategy, however, cannot be implemented in Europe, where the bulk of universities performing scientific research are public. ${ }^{30}$ We have to rely on qualitative information derived from the surveys. We explicitly asked the TTOs to identify the outcomes pursued via their royalty sharing schemes.

The results to this question are reported in Table 7. Interestingly, most of the TTOs claim to use royalty shares to incentivise university patenting and to improve their scientific production. However, they are relatively uninterested in using royalty sharing to maximise licensing income - less than a third mentioned being interested in maximising total licensing revenue (27\% in Portugal, and $31 \%$ in Spain), or TTO revenue (9\% in Portugal, and 5\% in Spain). This lack of interest in generating licensing income anticipates poor commercialisation perspectives for inventions. This perception was backed up by comments from several respondents to the inventors' survey, pointing out the inability of their TTO to commercialise inventions as the main reason for not caring about royalty sharing. The general feeling is perhaps best captured in the following words of one scientist: "who cares about getting $100 \%$ of nothing?"

Overall, the feedback from the surveys is consistent with the econometric results reported in Table 5, where the proxies for the quality of the TTO at commercialising inventions (i.e., the size and age of the TTO) are generally found not to be significant (with only age having a positive effect on patenting in Portugal).

\section{[INSERT TABLE 7]}

Inventors' ability effect - Inventors would certainly not respond to royalty incentives if their ability to perform applied research was such that their chances of producing licensable inventions were non-existent. We use the inventors' survey to determine whether inventors capable of producing high quality research are better informed about

\footnotetext{
${ }^{29}$ This is the strategy adopted by Lach and Schankerman (2008). Belenzon and Schankerman (2009) report that private universities are more likely to adopt incentive pay. In contrast, public universities tend to care more about local development objectives, and often prefer to offer licenses to local start-up companies (at the expense of foregone license income).

${ }^{30}$ Belenzon and Schankerman (2009) find that TTOs adopting incentive pay have between 30-40 percent more income per license. This effect is robust to differences in university ownership. We sought to implement this strategy but, unfortunately, almost none of the universities in our sample adopt incentive pay.
} 
royalty shares and more sensitive to the value of these shares. We construct two dependent variables based on the results reported in Table 6: a dummy variable with a value of one if inventors are aware of the royalty share, and zero otherwise; and a dummy variable with a value of one if inventors consider the royalty share to have a high or medium influence on their efforts to be inventive, and zero otherwise. We regress these two variables on three measures of inventor quality: whether the inventor's patents were filed in patent offices abroad; the number sexenios ${ }^{31}$ earned by the scientists, and; whether the inventor holds the title of 'professor', or not. Only the last indicator of quality is available for Portugal, and thus the results presented in this section are largely based on evidence from Spain. The results are reported in Table 8. In all cases, we control for gender, age, and a full set of university and field fixed effects.

In columns (1) and (5), our proxy for quality in applied research is a dummy variable with a value of one if the inventor's patent was filed at the USPTO or the EPO between 2005 and 2009, and zero if it was only filed at the national office (our preferred proxy). Inventors with patent applications abroad have a significantly higher degree of awareness of royalty shares, but they do not seem to find them to be more important for incentivising their research efforts. In the other columns, we use a set of variables that proxy a more generic type of quality: a set of dummy variables representing the different number of sexenios earned by a scholar (columns 2 and 6), and a dummy variable with a value of one if the inventor holds the title of 'professor' (columns 3 and 7). Neither of these variables seems to explain different attitudes towards royalty shares. If anything, inventors with four sexenios seem to be slightly more aware of royalty shares than inventors with no sexenios (but only at the $10 \%$ significance level). Finally, the results remain stable when all the variables are included simultaneously in the regression in columns (4) and (8). Interestingly, there are significant gender differences for the degree of awareness of royalty shares.

The finding that inventors with international patent applications are substantially more aware of the royalties is of particular interest, as it suggests that only high quality

\footnotetext{
${ }^{31}$ Sexenios are a supplement to a researcher's salary awarded following evaluation by a national agency (CNEAI, National Commission for the Evaluation of Research Activity). This evaluation gives substantial weight to publications in international journals listed in the ISI's Journal Citation Reports. In the Spanish research system, sexenios are seen as evidence of scientific excellence, and their use has had positive effects on Spain's scientific production (see Jiménez-Contreras et al., 2003).
} 
patents with a good chance of being licensed provoke inventors' curiosity for learning about royalty sharing. However, as Table 4 shows, the percentage of inventors with patent applications abroad in our sample is extremely low (below 10\%), which indicates that most inventors are producing patents with little commercial value and, hence, royalty share does not matter much to them. All in all, it appears that pecuniary incentives would matter more if patents were registered in patent offices abroad.

\section{[INSERT TABLE 8]}

\section{Conclusions}

The first research question that we have investigated in this paper is whether inventor royalty shares serve as an effective pecuniary incentive at Portuguese and Spanish universities. Evidence from a new inventors' survey indicates that one third of patent applicants are incentivised by current royalty sharing schedules, one third would be incentivised by higher royalty shares, and that the remaining third is totally insensitive to royalty sharing. However, plain regressions on university level datasets suggest that the incentive effects documented by the inventors' survey fail to translate into increased patenting or licensing income.

The second research question that we have sought to answer is whether incentive effects are diminished by environmental factors. While most inventors are sensitive to royalty sharing, only a few find royalty sharing to be highly influential. Why do royalty shares matter relatively little for those who are sensitive to them? It would seem that inventor royalty shares are not as influential as they could be on account of the poor commercial prospects of university inventions. Two possible reasons can be put forward to account for these poor expectations.

Firstly, TTOs may not be sufficiently focussed on commercialising inventions. It should be stressed that in Portugal, as in Spain, research universities are overwhelmingly public and that their TTOs eventually lack a clear commercial orientation. Indeed, in Portugal, some TTOs claim to be much more concerned with regional development and the boosting of local entrepreneurship through university spin-offs, than in licensing revenue (see Cartaxo and Godinho, 2014). In some cases, royalty-free licenses are 
offered to local firms simply to maximise the chances of university-generated knowledge being diffused among local economic agents. A further potential explanation for their lack of interest in maximising licensing income is that TTOs can rely on other sources of financing, including university funds, revenues from training, and consulting services, and also overheads charged to researchers from European projects. ${ }^{32}$ Our surveys for TTOs reflect this lack of interest in licensing income. Surprisingly, royalty sharing schemes seek to maximise the number of patents, and not the amount of licensing revenues, as one might expect. This suggests that TTOs fail to fully understand that royalty sharing can serve as an incentive by providing enhanced revenue opportunities for researchers. A line of future research could thus be to explore this apparently poor performance, researching on why the action of these TTOs seems not to be concentrated on licensing revenue, thus favouring other priorities and strategies as an alternative.

Secondly, many inventors seem to be failing to produce licensable inventions. Inventors whose patents were filed abroad (arguably higher quality patents) seem to care more about royalty sharing. However, only a few university inventions in Portugal and Spain were granted patents abroad. While the number of university patents in Portugal and Spain has grown dramatically in recent years, the quality of these patents might not yet be good enough to generate licensing income. It appears that in both countries, inventors are more interested in obtaining patents to enhance their reputation, and then in exploiting this reputation premium to foster technology transfer through $\mathrm{R} \& \mathrm{D}$ partnerships with industry. Another possibility could be that patents are used to strengthen technology transfer through the creation of spin-off firms. In neither of these cases would patenting be related to licensing. These results imply the need to develop further studies to research to what extent these effects are taking place, and whether a trade-off may actually be happening between licensing and the creation of spin-off firms.

\footnotetext{
${ }^{32}$ We should add that most TTOs, particularly those in Portugal, but also in Spain, are small, and still at a very early stage of the learning curve. However, over the last few years, the patenting policies of some TTOs have shifted from a "quantity", to a "quality" strategy. Indeed, a number of TTOs now seem to be more commercially aware of their licensing activities, and have attained a critical scale whereby they can successfully license their universities' patents.
} 
Clearly, a further explanation for the absence of any incentive effects attributable to royalty sharing could be that university scientists are disproportionately driven by traditional academic motivations (i.e., eponymy, prizes and publication). Despite this argument having been taken into account by our analytical model, it has not been empirically tested in this paper. Indeed, it should be stressed that in Portugal and Spain alike, more importance has traditionally been attached to academic activities, such as publishing, for obtaining tenure and other career promotions, than to patents or licensing. Thus, classic academic incentives can be said to impose a lower importance for the pay-off from commercially-oriented research: scientists will only devote effort to producing commercially-oriented inventions if the expected gains from so doing are greater than the gains from producing publications (i.e., the possibility of obtaining tenured positions, promotions, and eventually wage increases).

Other explanations for our results, which could also be explored by future research, include the appropriability regime of the technologies developed by university inventors and the possible geographical effects. Some highly valuable technologies produced by university inventors might not be adequately protected by patents. Unpatented technologies, for which property rights are not well delimited, are more difficult to be exchanged in the marketplace through licensing. But even if university technologies were suitable for patent protection, geographical effects could be a limiting factor for their commercialisation. TTOs belonging to smaller universities may lack the capacity to negotiate licenses with potential customers located much beyond the university's region, even when using the services of technology brokers. The impossibility to reach global markets would considerably restrict the potential set of licensees to local, mainly low-tech, firms. Moreover, in future studies it could be interesting to assess whether the emphasis of some TTOs on regional technology transfer might have a higher social return than the alternative of focussing mostly on licensing to external licensees.

Our paper has policy implications. Most inventors have been found to care about royalty sharing. However, in practice, only a few of such sensitive inventors are highly influenced by royalty sharing. Hence, it would seem that royalty sharing has the potential for achieving much stronger incentive effects. Understanding how to unfold this potential is of primary policy interest. Three courses of action can be taken. First, most of the inventors that have been defined as being sensitive, but non-incentivised, 
are unaware of the royalty sharing schedules in force. The minimum threshold value for which these inventors would be willing to increase their effort is often equal, or below current inventor royalty shares. So a good starting point would consist of informing inventors about royalty sharing. Second, both TTOs and inventors need to acquire greater commercial orientation, in order to ensure that the licensing income being shared is non-trivial. TTOs would have to commit themselves to pro-active commercialisation practices, including searching for licensees, and not just encouraging invention disclosure and undertaking the ensuing administrative tasks. Given that most Portuguese and Spanish firms are not technology-based, the demand for licenses is primarily from abroad, which means a successful licensing strategy would require the specific targeting of international licensees. Similarly, scientists will have to become more commercially-oriented. In other words, scientists need to be able to produce inventions that can be economically exploited through patenting and licensing. Third, most TTOs in Portugal and Spain are rather small, and it is very hard for each to have the full expertise needed to successfully explore their patent portfolios. A possibility to consider, is the stimulation of the merger of TTOs to build critical mass, or at least to enhance their coordination to target international licensees.

However, it is not our wish to overstate the policy implications, as it might simply not be optimal from a welfare viewpoint to maximise licensing income. Indeed, universities in Spain and Portugal are public and, as such, are likely to prioritise other goals. For instance, they might prefer to maximise regional development, for which there are forms of technology transfer, such as spin-off creation and $R \& D$ cooperation agreements which are likely to better serve this purpose. Spin-offs, for example, tend to be located in the same region as the university from which they emerge, thereby guaranteeing regional development (Zhang, 2009; Zucker et al., 1998). Licensing, on the other hand, only spurs regional development if inventions are licensed to local licensees, which might be at odds with maximising licensing income. ${ }^{33}$ Moreover, universities might prefer their researchers to commit to academic research, as they may perceive this to be a greater source of spillovers than commercially-oriented research.

\footnotetext{
33 Belenzon and Schankerman (2009) find that public universities with strong local development objectives see their licensing income reduced, as they prefer to license to local firms (even if it is at a discount).
} 
The apparent lack of interest shown by Portuguese and Spanish universities in licensing income might therefore be totally legitimate. However, TTOs in both countries do use royalty sharing schemes to improve technology transfer. It is perhaps this coexistence of royalty sharing policies and the lack of interest in licensing income that is somewhat puzzling, as royalty sharing is most effective when combined with a credible commitment to commercialisation. 
Acknowledgments

The authors wish to thank TTO managers and respondents in both countries for participating in the surveys, and also for their interest in clarifying our additional concerns, together with those researchers who answered and commented on the surveys; the Portuguese Fundação para a Ciência e Tecnologia for financial support; and, finally; participants at the DRUID Academy 2014 Conference and the Triple Helix XII 2014 , for their comments on the draft paper. The authors also wish to thank Alexandra Rosa and Ángela Mediavilla, who helped build the surveys at the Universities of Lisbon and Barcelona, respectively. 


\section{REFERENCES}

Azagra-Caro, J. 2011. Do public research organisations own most patents invented by their staff? Science and Public Policy 38, 237-250.

Baldini, N. 2006. Patenting in Universities. Research Evaluation 15, 197-207.

Baldini, N., Grimaldi, R., Sobrero, M., 2007. To patent or not to patent? A survey of Italian inventors on motivations, incentives, and obstacles to university patenting. Scientometrics, 70, 333-354.

Baldini, N. 2008. The Patenting Universities: Problems and Perils, in Sri Krishna, C. (P), Academic patents: Emerging Issues and Challenges, pp. 48-59, ICFAI University Press.

Baldini, N. 2010. Do royalties really foster university patenting activity? An answer from Italy. Technovation 30, 109-116.

Belenzon, S., Shankerman, M., 2009. University knowledge transfer: private ownership, incentives, and local development objectives. Journal of Law and Economics 52, 111-144.

Bercovitz, J., Feldmann, M. (2006). Entrepreneurial Universities and Technology Transfer: A Conceptual Framework for Understanding Knowledge-Based Economic Development. Journal of Technology Transfer, 31, 175-188.

Bodas Freitas, I.M., Nuvolari, A., 2012. Traditional Versus Heterodox Motives for Academic Patenting: Evidence from the Netherlands. Industry and Innovation, 19, 671-695.

Caldera, A., Debande, O., 2010. Performance of Spanish universities in technology transfer: An empirical analysis. Research Policy 39, 1160-1173.

Cartaxo, R., Godinho, M.M., 2014. University patenting, licensing and technology transfer: how organizational context and available resources determine performance. Submitted, under revision. Mimeo.

Etzkowitz, H., 2002. MIT and the Rise of Entrepreneurial Science. Routledge

Friedman, J., Silberman, J., 2003. University Technology Transfer: Do Incentives, Management and Location Matter? Journal of Technology Transfer, 28, 17-30.

Geuna, A., Rossi, F. 2011. Changes to university IPR regulations in Europe and the impact on academic patenting. Research Policy 40, 1068-1076.

Göktepe-Hulten, D., and Mahagaonkar, P., 2010. Inventing and patenting activities of scientists: in the expectation of money or reputation? The Journal of Technology Transfer, 35, 401-423. 
Jaffe, A., 1989. Real effects of academic research. American Economic Review, 79, 957-970.

Jiménez-Contreras, E., de Moya Anegón, F., Delgado López-Cózar, E. 2003. The evolution of research activity in Spain. The impact of the National Commission for the Evaluation of Research Activity (CNEAI), Research policy 32, 123-142.

Lach, S., Schankerman, M., 2008. Incentives and invention in universities. Rand Journal of Economics 39, 403-433.

Lam, A. 2011. What motivates academic scientists to engage in research commercialisation: 'Gold', 'ribbon' or 'puzzle'? Research Policy 40, 1354-1368

Link, A., Siegel, D.S., 2005. Generating science-based growth: an econometric analysis of the impact of organizational incentives on university-industry technology transfer. The European Journal of Finance, The European Journal of Finance, vol. 11, No. 3, 169-181.

Lissoni, F. 2013. Academic Patenting in Europe: A Reassessment of Evidence and Research Practices. Industry and Innovation 20, 379-384.

Markman G.D., Gianiodis P.T., Phan P.H., Balkin D.B., 2004. Entrepreneurship from the ivory tower: Do incentive systems matter? Journal of Technology Transfer, 29, 353-364.

Owen-Smith, J., Powell, W. W. 2003. The expanding role of university patenting in the life sciences: Assessing the importance of experience and connectivity. Research Policy, 32(9), 1695-1711.

Perkmann, M., Tartari, V., McKelvey, M., Autio, E., Broström, A., D’Este, P., Fini, R., Geuna, A., Grimaldi, R., Hughes, A., Krabel, S., Kitson, M., Llerena, P., Lissoni, F., Salter, A., Sobrero, M., 2013. Academic engagement and commercialisation: A review of the literature on university-industry relations. Research Policy 42, 423-442.

Sampat, B.N-, Mowery, D.C., Ziedonis, A.A., 2003. "Changes in University Patent Quality after Bayh-Dole: A Re-Examination." International Journal of Industrial Organization. 21, 1371-1390

Sauermann, H., Cohen W., Stephan, P., 2010. Doing well or doing good? The motives, incentives, and commercial activities of academic scientists and engineers. DRUID Summer Conference on "Opening Up Innovation: Strategy, Organization and Technology", Imperial College London Business School. 
Stephan, P. E., 1996. The Economics of Science, Journal of Economic Literature 34, 1199-1235.

Verspagen, B., 2006. University research, intellectual property rights and European innovation systems. Journal of Economic Surveys 20, 607-632.

Walter, T., Christoph, I., Maur, R., Brettel, M., 2013. Grace, gold, glory? Exploring incentives for invention disclosure in the university context? Journal of Technology Transfer. Published online. DOI 10.1007/s10961-013-9303-1.

Zhang, J., 2009. The performance of university spin-offs: an exploratory analysis using venture capital data. The Journal of Technology Transfer, 34, 255-285.

Zucker, L., Darby, M., Brewer, M., 1998. Intellectual Human Capital and the Birth of U.S. Biotechnology Enterprises. The American Economic Review, 88, 290-306 


\section{FIGURES}

Figure 1. Distribution of inventor royalty shares in Portugal and Spain
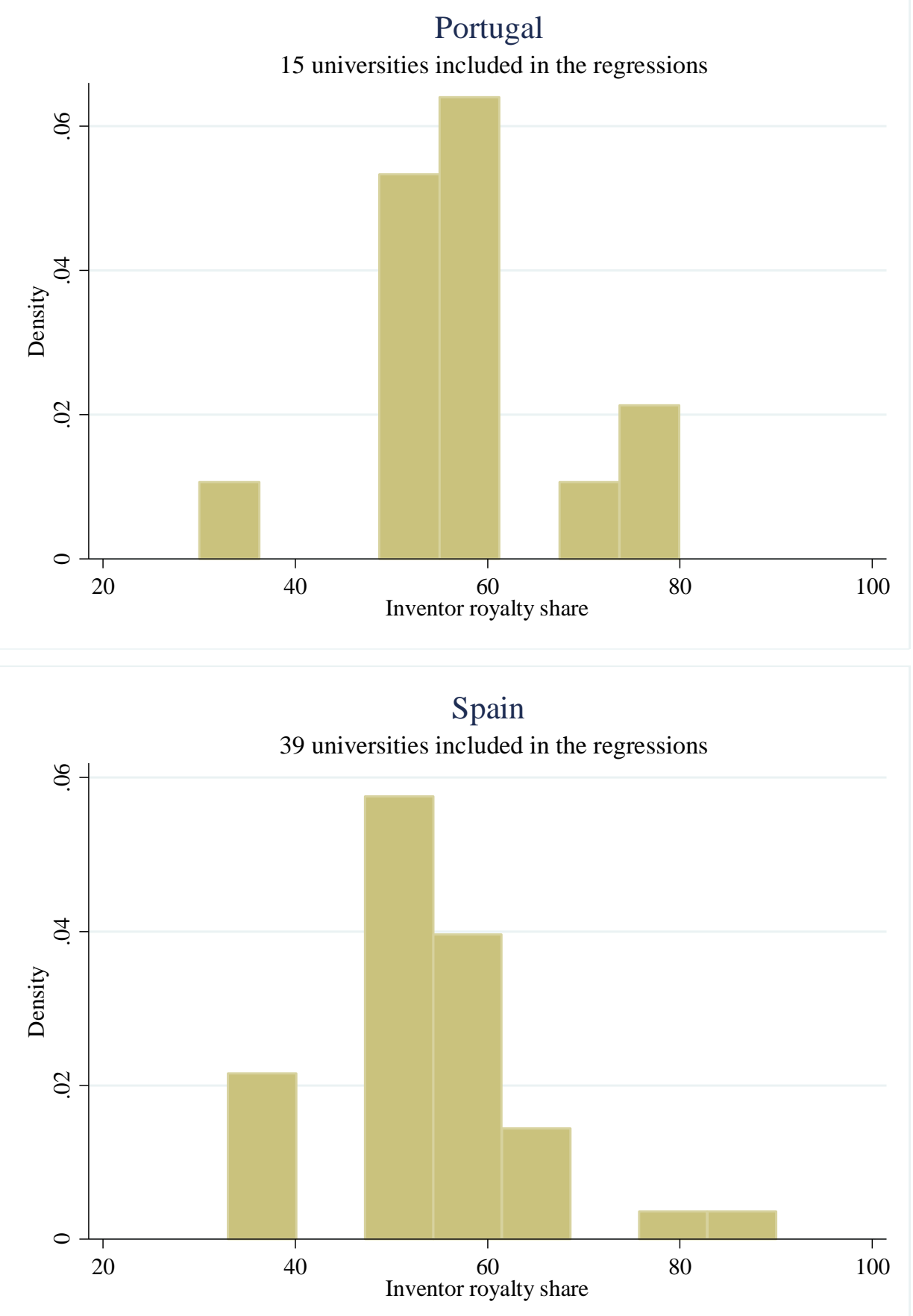
Figure 2. Sensitive and incentivized inventors.

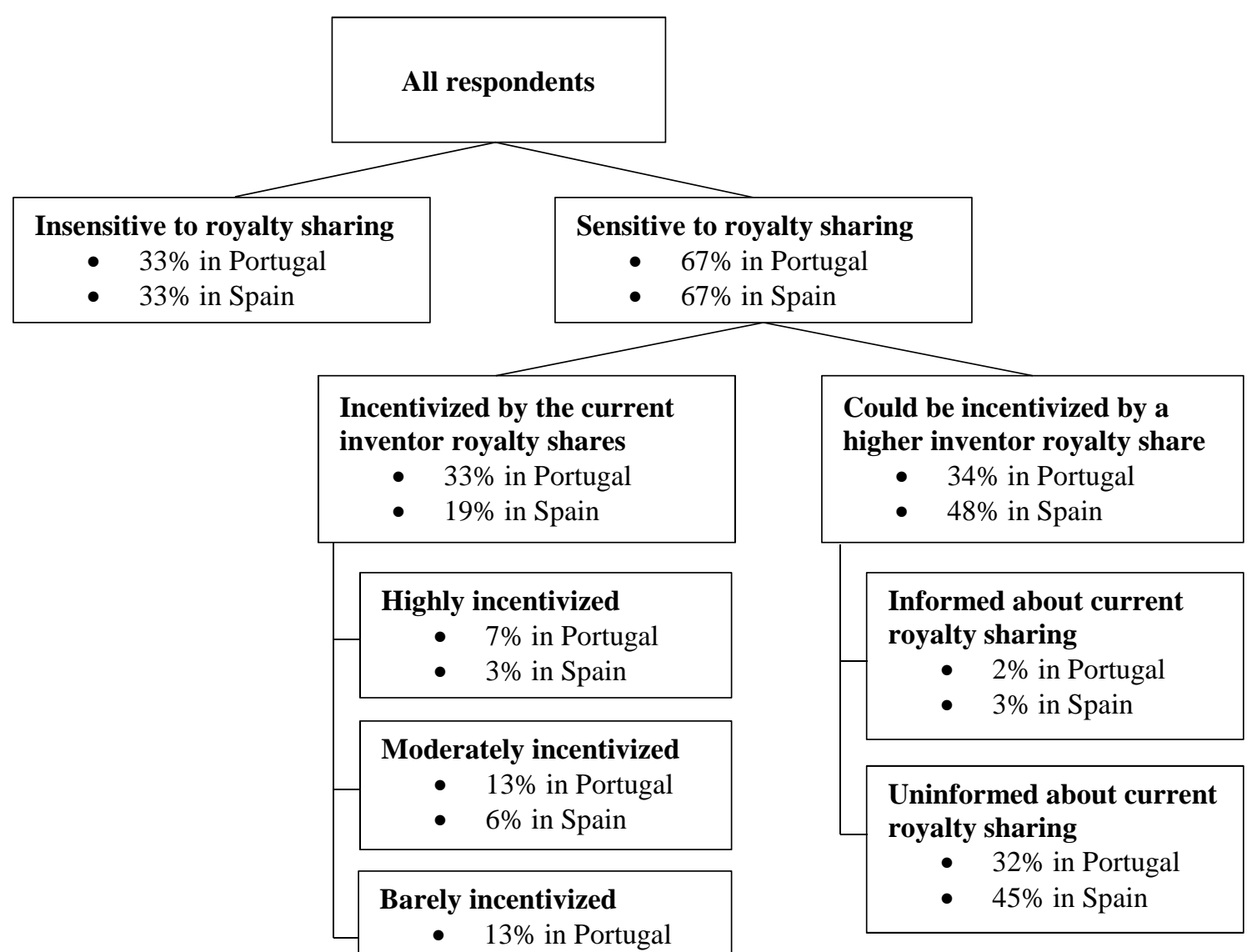

Notes: The percentages in this figure are calculated with information provided in Table 6. Percentages are always with respect to the total number of respondents and they are based on the following definitions are calculations:

Insensitive to royalty sharing: respondents that do not (or would not) react to any value of the inventor royalty share. Consistently with this definition, the percentage of respondents that are insensitive to royalty sharing is obtained by dividing the number of "no" in question 3 over the total number of respondents in the survey $(0.49 * 141 / 212$ in Portugal and $0.41 * 492 / 606$ in Spain).

Sensitive to royalty sharing: respondents that (would) react to sufficiently large values of the inventor royalty share. Following this definition, the percentage of respondents that are sensitive to royalty sharing is obtained as $1-\%$ of respondents insensitive to royalty sharing.

Incentivized by the current inventor royalty shares: respondents who state that royalty shares have had a "high", "medium" or "low" influence on their decision to generate patentable inventions. Consistent with this definition, we obtain the percentage of respondents incentivized by the current inventor royalty shares by multiplying the percentage of "yes" in question 1 by the sum of the percentage of "high", "medium" and "low" in question $2(48 \% *(14 \%+28 \%+28 \%)$ in Portugal and $28 \% *(11 \%+23 \%+34 \%)$ in Spain). Similarly, we obtain the percentage of inventors that are highly, moderately and barely incentivized by multiplying the percentage of "yes" in question 1 by the percentage of "high", "medium" and "low" in question 2 respectively.

Could be incentivized by a higher inventor royalty share: respondents who are not incentivized by the current royalty shares, but who state that there is an inventor royalty share for which they would be willing to increase their effort. Consequently, we have calculated the percentage of respondents that could be incentivized by a higher inventor royalty share by dividing the number of "yes" in question 3 by the total number of respondents in the survey $(0.51 * 141 / 212$ in Portugal and $0.59 * 492 / 606$ in Spain). Notice that the pool of sensitive respondents that could be incentivized is formed by two subgroups: a very small group of respondents who are aware of the royalty shares (answer "none" in question 2 and "yes" in question 3) and a large group of inventors who are not aware of the current royalty shares (answer "no" in question 1 and "yes" in question 3). 


\section{TABLES}

Table 1. Literature review

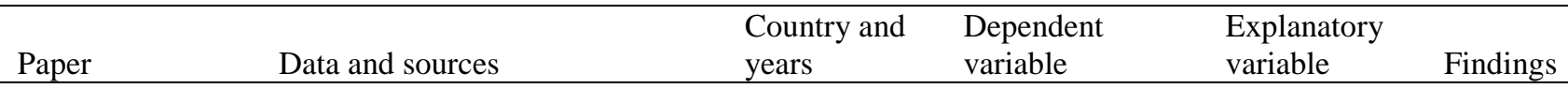

GROUP A. Unit of analysis: university / Type of country: high licensing income

\begin{tabular}{|c|c|c|c|c|c|}
\hline $\begin{array}{l}\text { Friedman and } \\
\text { Silberman } \\
(2003)\end{array}$ & $\begin{array}{l}\text { Panel of universities. } \\
\text { Sources: AUTM Licensing } \\
\text { Survey; National Research } \\
\text { Council. }\end{array}$ & $\begin{array}{l}\text { US, 1997- } \\
1999\end{array}$ & $\begin{array}{l}\text { Number of } \\
\text { licenses and } \\
\text { licensing income }\end{array}$ & Royalty share & $\begin{array}{l}\text { (1) No effect on nu } \\
\text { of licenses; (2) Pos } \\
\text { effect on licensing } \\
\text { income }\end{array}$ \\
\hline $\begin{array}{l}\text { Markman et al. } \\
(2004)\end{array}$ & $\begin{array}{l}\text { Cross-section of universities. } \\
\text { Sources: AUTM Licensing } \\
\text { Survey; own survey to UTTO } \\
\text { directors; web-based searches; } \\
\text { USPTO. }\end{array}$ & US, 1999 & $\begin{array}{l}\text { Number of } \\
\text { equity licenses }\end{array}$ & Royalty share & (1) Negative effect \\
\hline $\begin{array}{l}\text { Link and Siegel } \\
(2005)\end{array}$ & $\begin{array}{l}\text { Panel of universities. } \\
\text { Sources: Own field interviews to } \\
\text { entrepreneurs, administrators } \\
\text { and scientists from five } \\
\text { universities; AUTM Licensing } \\
\text { Survey. }\end{array}$ & $\begin{array}{l}\text { US, 1991- } \\
1998\end{array}$ & $\begin{array}{l}\text { Number of } \\
\text { licenses and } \\
\text { licensing income }\end{array}$ & Royalty share & (1) Positive effect \\
\hline $\begin{array}{l}\text { Lach and } \\
\text { Schankerman } \\
(2008)\end{array}$ & $\begin{array}{l}\text { Panel of universities. } \\
\text { Sources: AUTM Licensing } \\
\text { Survey; own survey to TLOs. }\end{array}$ & $\begin{array}{l}\text { US, } 1997- \\
1999\end{array}$ & $\begin{array}{l}\text { Licensing } \\
\text { income }\end{array}$ & Royalty share & (1) Positive effect \\
\hline $\begin{array}{l}\text { Belenzon and } \\
\text { Schankerman }\end{array}$ & $\begin{array}{l}\text { Panel of universities. } \\
\text { Sources: Own survey to TLOs; }\end{array}$ & $\begin{array}{l}\text { US, } 1995- \\
2005\end{array}$ & $\begin{array}{l}\text { Income per } \\
\text { license }\end{array}$ & $\begin{array}{l}\text { Performance } \\
\text { pay in TTO }\end{array}$ & (1) Positive effect \\
\hline
\end{tabular}

(2009)

AUTM Licensing Survey; patent data from the USPTO.

GROUP B. Unit of analysis: university / Type of country: low licensing income

\begin{tabular}{|c|c|c|c|c|c|}
\hline Baldini (2010) & $\begin{array}{l}\text { Panel of universities. } \\
\text { Source: Italian Ministry of } \\
\text { Education and PATUNIT } \\
\text { database }\end{array}$ & $\begin{array}{l}\text { Italy, 1998- } \\
2002\end{array}$ & Patent counts & Royalty share & (1) Positive effect \\
\hline $\begin{array}{l}\text { Caldera and } \\
\text { Debande (2010) }\end{array}$ & $\begin{array}{l}\text { Panel of universities. } \\
\text { Source: Spanish TTO Network } \\
\text { (RedOTRI) Survey }\end{array}$ & $\begin{array}{l}\text { Spain, 2001- } \\
2005\end{array}$ & $\begin{array}{l}\text { Number of } \\
\text { licenses and } \\
\text { licensing income }\end{array}$ & Royalty share & $\begin{array}{l}\text { (1) No effect on number } \\
\text { of licenses; (2) Positive } \\
\text { effect on licensing } \\
\text { income }\end{array}$ \\
\hline
\end{tabular}

GROUP C. Unit of analysis: inventor / Type of country: high licensing income Cross section of doctorate recipients.

Sauermann et al. Sources: Survey of Doctorate

(2010) Recipients (National Science

Foundation); AUTM Licensing

Survey; National Research

Council

Cross-section of scientists.

Göktepe and Mahagaonkar (2010) survey on the commercial activities of 2,500 scientists affiliated to 67 institutes

US, $2003 \quad$ Involvement in patenting

Royalty share

(1) No effect of inventor royalty share; (2)

Positive effect of salary in Physical Sciences but not in Life Sciences and Engineering.

(1) Expectation of

Germany, Involvement in Monetary and financial benefits is not 2007 disclosure and reputation important; (2) patenting expectations expectation to increase reputation is important.

GROUP D: Unit of analysis: inventor / Type of country: low licensing income

\begin{tabular}{|c|c|c|c|c|c|}
\hline $\begin{array}{l}\text { Baldini et al. } \\
(2007)\end{array}$ & $\begin{array}{l}\text { Cross-section of university } \\
\text { inventors. } \\
\text { Source: own survey to university } \\
\text { inventors. }\end{array}$ & Italy, 2003 & $\begin{array}{l}\text { Involvement in } \\
\text { patenting }\end{array}$ & $\begin{array}{l}\text { Personal } \\
\text { earnings }\end{array}$ & $\begin{array}{l}\text { (1) Personal earnings do } \\
\text { not represent a main } \\
\text { incentive; (2) Reputation } \\
\text { matters. }\end{array}$ \\
\hline
\end{tabular}




\begin{tabular}{|c|c|c|c|c|c|c|c|c|}
\hline \multirow[b]{5}{*}{ License income (in thousands of Euros) } & \multicolumn{4}{|c|}{ Portugal } & \multicolumn{4}{|c|}{ Spain } \\
\hline & Mean & S.D. & Min & Max & Mean & S.D. & Min & Max \\
\hline & \multicolumn{8}{|c|}{ License revenue regression } \\
\hline & \multicolumn{4}{|c|}{$(\mathrm{N}=7, \mathrm{~N} * \mathrm{~T}=29)$} & \multicolumn{4}{|c|}{$(\mathrm{N}=39, \mathrm{~N} * \mathrm{~T}=155)$} \\
\hline & 10.27 & 50.82 & 0 & 274 & 66.32 & 99.59 & 0 & 600 \\
\hline Royalty share & 55.00 & 7.93 & 50 & 80 & 53.87 & 10.71 & 33 & 90 \\
\hline Pre-sample patent applications & 10.96 & 17.68 & 1 & 49 & 8.20 & 8.06 & 1 & 36 \\
\hline Size of TTO & 5.20 & 2.88 & 1 & 9 & 17.31 & 15.71 & 3 & 83 \\
\hline Age of TTO in 2007 & 5.37 & 3.31 & 0 & 11 & 15.95 & 3.52 & 4 & 20 \\
\hline Faculty size & 991 & 462 & 424 & 1,924 & 2,812 & 4,565 & 546 & 40,879 \\
\hline R\&D (in thousands of Euros) & na & na & na & na & 33,243 & 25,676 & 3,825 & 119,000 \\
\hline \multirow[t]{3}{*}{ Science park dummy variable } & 0.79 & 0.41 & 0 & 1 & 0.69 & 0.46 & 0 & 1 \\
\hline & \multicolumn{8}{|c|}{ Patent application regression } \\
\hline & \multicolumn{4}{|c|}{$(\mathrm{N}=15, \mathrm{~N} * \mathrm{~T}=56)$} & \multicolumn{4}{|c|}{$(\mathrm{N}=39, \mathrm{~N} * \mathrm{~T}=188)$} \\
\hline Patent applications & 9.52 & 10.06 & 0 & 54 & 11.95 & 11.47 & 0 & 72 \\
\hline Royalty share & 54.82 & 8.89 & 30 & 80 & 53.67 & 11.43 & 33 & 90 \\
\hline Pre-sample patent applications & 9.24 & 13.22 & 0 & 49 & 7.74 & 7.66 & 1 & 36 \\
\hline Size of TTO & 4.47 & 2.80 & 1 & 9 & 16.35 & 14.96 & 3 & 83 \\
\hline Age of TTO in 2007 & 5.20 & 4.77 & 0 & 17 & 15.74 & 3.65 & 4 & 20 \\
\hline Faculty size & 961 & 417 & 424 & 1924 & 2,617 & 4,192 & 546 & 40,879 \\
\hline R\&D (in thousands of Euros) & na & na & na & na & 31,225 & 24,627 & 2,575 & 119,000 \\
\hline Science park dummy variable & 0.64 & 0.48 & 0 & 1 & 0.69 & 0.46 & 0 & 1 \\
\hline
\end{tabular}


Table 3. Variable definitions and sources

\begin{tabular}{|c|c|c|c|}
\hline Variable & Definition & Source Portugal & Source Spain \\
\hline $\begin{array}{l}\text { Licensing income (in } \\
\text { thousands of Euros) }\end{array}$ & $\begin{array}{l}\text { Total licensing income of the university in thousands of } \\
\text { Euros. It includes income not only from patents but also } \\
\text { from other sources such as software, databases or know- } \\
\text { how. In Spain, licensing income from patents is only } \\
\text { observed from } 2009 \text { onwards and accounted, on average, } \\
\text { for } 37,63 \text { and } 58 \% \text { of total licensing income in the years } \\
2009,2010 \text { and } 2011 \text { respectively. }\end{array}$ & Survey to TTOs & Red OTRI Surveys $^{1}$ \\
\hline Patent applications & Number of patent applications in the national offices & Portuguese patent office & $\begin{array}{l}\text { Spanish patent and } \\
\text { trademark office }\end{array}$ \\
\hline Inventor royalty share & $\begin{array}{l}\text { Share of license revenues that goes to the inventor as } \\
\text { established in the royalty sharing scheme of the university }\end{array}$ & Survey to TTOs & $\begin{array}{l}\text { Survey to TTOs and } \\
\text { tables in González- } \\
\text { Albo-Manglano and } \\
\text { Zulueta-García }(2007)^{2}\end{array}$ \\
\hline $\begin{array}{l}\text { Pre-sample patent } \\
\text { applications }\end{array}$ & $\begin{array}{l}\text { Average number of patent applications in the national } \\
\text { office in the years } 2005 \text { and } 2006\end{array}$ & Portuguese patent office & $\begin{array}{l}\text { Spanish patent and } \\
\text { trademark office }\end{array}$ \\
\hline Size of TTO & $\begin{array}{l}\text { Number of workers in the TTO that have a technical } \\
\text { profile }\end{array}$ & 2008 Survey to TTOs & Red OTRI Surveys ${ }^{1}$ \\
\hline Age of TTO in 2007 & Age of the TTO in 2007 & 2008 Survey to TTOs & Red OTRI Surveys ${ }^{1}$ \\
\hline Faculty size & $\begin{array}{l}\text { Number of researchers in the university (in Spain this } \\
\text { corresponds to the PDI categories described in the } \\
\text { LOMLOU) }\end{array}$ & http://w3.dgeec.mec.pt/rebides/20XX/ & Red OTRI Surveys ${ }^{1}$ \\
\hline $\begin{array}{l}\text { R\&D (in thousands of } \\
\text { Euros) }\end{array}$ & $\begin{array}{l}\text { Total amount of research support committed to the } \\
\text { university through programs for financing public research }\end{array}$ & na & Red OTRI Surveys $^{1}$ \\
\hline $\begin{array}{l}\text { Science park dummy } \\
\text { variable }\end{array}$ & $\begin{array}{l}\text { A dummy variable with value one if the university has a } \\
\text { science park. }\end{array}$ & $\begin{array}{l}\text { Own elaboration via internet searches } \\
\text { and phone calls to universities }\end{array}$ & Red OTRI Surveys ${ }^{1}$ \\
\hline
\end{tabular}

Notes: 1. http://www.crue.org/Publicaciones/Paginas/Informe-RedOTRI.aspx?Mobile=0; 2 . The tables with the royalty shares can be found in http://www.scielo.br/pdf/ci/v36n1/a05v36n1.pdf. 
Table 4. Inventors' characteristics (from the inventors' survey)

\begin{tabular}{|c|c|c|c|c|}
\hline & \multicolumn{2}{|c|}{ Portugal } & \multicolumn{2}{|c|}{ Spain } \\
\hline & Mean & S.D. & Mean & S.D. \\
\hline Age & 46.89 & 8.52 & 46.39 & 9.27 \\
\hline Male & 0.71 & & 0.77 & \\
\hline Permanent contract & 0.54 & & 0.82 & \\
\hline \multicolumn{5}{|l|}{ Position } \\
\hline $\mathrm{PhD}$ student & 0.00 & & 0.04 & \\
\hline Postdoc & 0.02 & & 0.08 & \\
\hline Assistant professor & 0.43 & & 0.09 & \\
\hline Associate professor & 0.37 & & 0.51 & \\
\hline Professor & 0.17 & & 0.29 & \\
\hline Number of "sexenios", & na & & 2.15 & 1.69 \\
\hline International patent applications ${ }^{\mathrm{a}}$ & na & & 0.09 & \\
\hline \multicolumn{5}{|l|}{ Field } \\
\hline Architecture & 0.01 & & 0.02 & \\
\hline Biology $y^{a}$ & na & & 0.06 & \\
\hline Chemistry & 0.05 & & 0.14 & \\
\hline Engineering & 0.47 & & 0.37 & \\
\hline Medicine & 0.03 & & 0.05 & \\
\hline Pharmacy $^{\mathrm{b}}$ & 0.05 & & 0.04 & \\
\hline Physics $^{\mathrm{a}}$ & na & & 0.07 & \\
\hline Science and Technology ${ }^{b}$ & 0.27 & & na & \\
\hline Technology and Management & 0.02 & & na & \\
\hline Telecomunications & na & & 0.06 & \\
\hline Other & 0.10 & & 0.19 & \\
\hline
\end{tabular}

Notes: The statistics for Portugal are based on the 212 responses for which we have full information. The statistics for Spain are based on the 606 responses for which we have full information except for the variable "International patent applications" for which we only have information for 573 researchers. The variable "International patent applications" is a dummy variable with value one if the inventor has international patent applications (in the USPTO and EPO offices) and zero otherwise. This was not obtained directly from the survey but from matching the survey with the original database on patents retrieved from the patent offices. All the variables are dummy variables except for "Age" and "Number of sexenios" and we only report standard deviations for these last two variables. a) The number of "Sexenios" is a recognition awarded to Spanish scholars that does not exist in Portugal (see footnote 23 for fuller explanation), the number of international patent applications by scientist is available for Spain but not for Portugal, the fields "Biology" and "Physics" are specific to the Spanish survey. b) The fields "Science and Technology" and "Technology and Management" are specific to the Portuguese survey. 
Table 5. License revenue, patent applications and inventor royalty shares

\begin{tabular}{|c|c|c|c|c|c|c|c|c|}
\hline & \multicolumn{4}{|c|}{ Portugal } & \multicolumn{4}{|c|}{ Spain } \\
\hline & \multicolumn{2}{|c|}{ Patent applications } & \multicolumn{2}{|c|}{ License revenue } & \multicolumn{2}{|c|}{ Patent applications } & \multicolumn{2}{|c|}{ License revenue } \\
\hline & $(1)$ & $(2)$ & $(3)$ & $(4)$ & $(5)$ & $(6)$ & $(7)$ & $(8)$ \\
\hline \multirow[t]{2}{*}{ Royalty share } & 0.00 & -0.01 & $0.05^{*}$ & 0.03 & 0.01 & $0.01^{*}$ & 0.01 & 0.01 \\
\hline & $(0.02)$ & $(0.02)$ & $(0.02)$ & $(0.02)$ & $(0.01)$ & $(0.00)$ & $(0.02)$ & $(0.02)$ \\
\hline \multirow[t]{2}{*}{$\log ($ Pre-sample patent applications $)$} & $0.53^{* * *}$ & 0.28 & -0.21 & 1.65 & $0.78^{* * * *}$ & $0.58^{* * *}$ & $0.88^{* * * *}$ & 0.28 \\
\hline & $(0.14)$ & $(0.17)$ & $(0.25)$ & $(2.57)$ & $(0.07)$ & $(0.10)$ & $(0.25)$ & $(0.35)$ \\
\hline \multirow[t]{2}{*}{$\log (\mathrm{TTO} /$ Faculty $)$} & & $-0.36^{*}$ & & -9.98 & & 0.10 & & 0.17 \\
\hline & & $(0.20)$ & & $(9.02)$ & & $(0.08)$ & & $(0.39)$ \\
\hline \multirow[t]{2}{*}{ Age TTO } & & $0.26^{* * *}$ & & 4.12 & & 0.03 & & -0.04 \\
\hline & & $(0.12)$ & & $(4.06)$ & & $(0.06)$ & & $(0.25)$ \\
\hline \multirow[t]{2}{*}{ Age TTO squared } & & $-0.01^{*}$ & & -0.49 & & -0.00 & & 0.00 \\
\hline & & $(0.01)$ & & $(0.51)$ & & $(0.00)$ & & $(0.01)$ \\
\hline \multirow[t]{2}{*}{$\log ($ Faculty $)$} & & -0.12 & & -10.45 & & $0.41^{* * *}$ & & 0.63 \\
\hline & & $(0.25)$ & & (11.39) & & $(0.16)$ & & $(0.39)$ \\
\hline \multirow[t]{2}{*}{$\log (\mathrm{R} \& \mathrm{D} /$ Faculty $)$} & & & & & & $0.23^{*}$ & & 0.51 \\
\hline & & & & & & $(0.13)$ & & $(0.39)$ \\
\hline \multirow[t]{2}{*}{ Science park dummy variable } & & -0.33 & & -0.83 & & 0.05 & & -0.00 \\
\hline & & $(0.42)$ & & $(0.49)$ & & $(0.12)$ & & $(0.47)$ \\
\hline \multirow[t]{2}{*}{ Constant } & 0.72 & 0.09 & $-2.21^{*}$ & 16.29 & 0.12 & $-6.10^{* * *}$ & 1.15 & -10.53 \\
\hline & (1.07) & $(1.90)$ & $(0.87)$ & $(23.60)$ & $(0.28)$ & $(2.96)$ & $(0.92)$ & $(8.80)$ \\
\hline Observations & 56 & 56 & 29 & 29 & 188 & 188 & 155 & 155 \\
\hline Universities & 15 & 15 & 7 & 7 & 39 & 39 & 39 & 39 \\
\hline R-squared & 0.34 & 0.45 & 0.28 & 0.48 & 0.66 & 0.71 & 0.24 & 0.34 \\
\hline
\end{tabular}

Notes: $* * *, * *$ and $*$ indicate significance at the $1 \%, 5 \%$ and $10 \%$ levels, respectively. Clustered (by university) robust standard errors in parentheses. The dependent variable is the log of one plus the number of patent applications and total license revenue. All the regressions include a full set of time dummies. 
1) Do you know what the inventor royalty share is in your university? Yes (\%) $\quad 48 \quad 28$

$\begin{array}{lrr}\text { No }(\%) & 52 & 72\end{array}$

$\begin{array}{lrl}\text { \# Respondents } & 212 & 606\end{array}$

2) What is the influence of the inventor royalty share on your decision to generate patentable inventions? (Addressed to respondents who answer "yes" to question 1)

High (\%) $14 \quad 11$

Medium (\%) $\quad 28 \quad 23$

Low (\%) $\quad 28 \quad 34$

None (\%) $\quad 30 \quad 33$

\# Respondents $\quad 102 \quad 168$

3) Is there a minimum threshold above which you would find it worthwhile to devote efforts to producing patentable inventions? (Addressed to respondents who answer "no" to question 1 or "none" to question 2)

Yes $(\%) \quad 51 \quad 59$

No (\%) $\quad 49 \quad 41$

\# Respondents $\quad 141 \quad 492$

4) What is this threshold? (Addressed to researchers who answer "no" to question 1 or "none" to question 2 , and "yes" to question 3)

4.1) All researchers

$\begin{array}{llr}\text { Mean } & 43.8 & 28.9\end{array}$

$\begin{array}{lrr}\text { S.D. } & 20.4 & 20\end{array}$

$\begin{array}{lll}\text { \# Respondents } & 72 & 232\end{array}$

4.2) Researchers who know the current royalty shares

Mean $\quad 50 \quad 40.41$

$\begin{array}{lll}\text { S.D. } & 0 & 27.7\end{array}$

\# Respondents $\quad 5 \quad 17$

4.3) Researchers who do not know the current royalty shares

Mean $\quad 43.3$

S.D. $\quad 21.1$

\# Respondents $\quad 67 \quad 215$

Difference 4.2)-4.3)

Mean

S.D.

$9.5 \quad 5$

p-value

$0.5 \quad 0.015$


Table 7. Goals pursued with the established royalty share (from the TTO survey)

\begin{tabular}{|c|c|c|}
\hline & Portugal & spain \\
\hline a. Incentivize an increase in university patenting (\%) & 50 & 93 \\
\hline b. Maximize total income from patents $(\%)$ & 27 & 31 \\
\hline c. Maximize university (TTO) revenues (\%) & 9 & 5 \\
\hline d. Favor the development of "spin-off" $(\%)$ & 23 & 10 \\
\hline e. Improve the scientific production of the university $(\%)$ & 36 & 40 \\
\hline f. Attract high quality researchers $(\%)$ & 9 & 2 \\
\hline Total number of respondents & 22 & 45 \\
\hline
\end{tabular}

Notes: the responses are not mutually exclusive. Most TTOs generally selected one or two goals (with a few even identifying three). 
Table 8. Inventors' quality and effectiveness of the royalty shares. Evidence for Spain (from the inventor's survey)

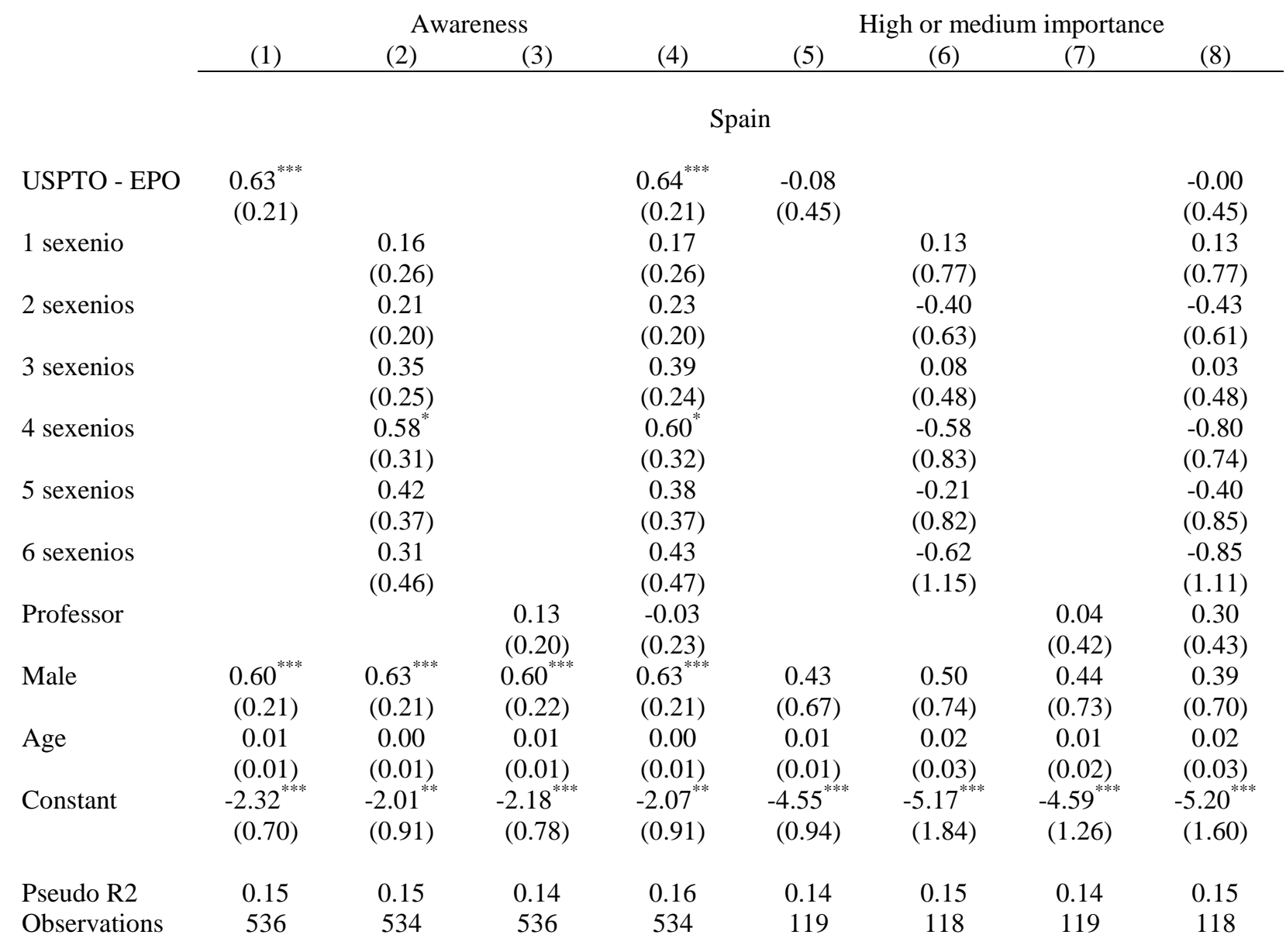

Portugal

$\begin{array}{lcc}\text { Professor } & 0.13 & -0.54 \\ & (0.67) & (0.68) \\ \text { Male } & 0.52^{*} & 0.63 \\ & (0.29) & (0.77) \\ \text { Age } & 0.01 & 0.04 \\ & (0.02) & (0.03) \\ \text { Constant } & 0.58 & -3.43^{* *} \\ & (0.82) & (1.38) \\ & 0.18 & 84 \\ \text { Pseudo R2 } & 181 & 84 \\ \text { Observations } & \text { Notes: ***, ** and * indicate significance at a 1\%, 5\% and 10\% level respectively. Clustered (at the university } \\ \text { level) robust standard errors in parentheses. Estimation method: probit. The dependent variables are a dummy } \\ \text { variable with value one if the inventor is aware of the inventor royalty share in her university (columns 1-4) and a } \\ \text { dummy variable if the inventor claims that the inventor royalty share was of high importance at stimulating her } \\ \text { effort (columns 5-8). All the regressions include a full set of university and field dummies. In the regressions we } \\ \text { use all the available observations from the surveys for which all the variables needed in the regressions have non- } \\ \text { missing values. }\end{array}$




\section{APPENDIX}

Table 1A. Replication of Table 5 estimates for Spain dropping the observations corresponding to the University of Cádiz and the University of Extremadura

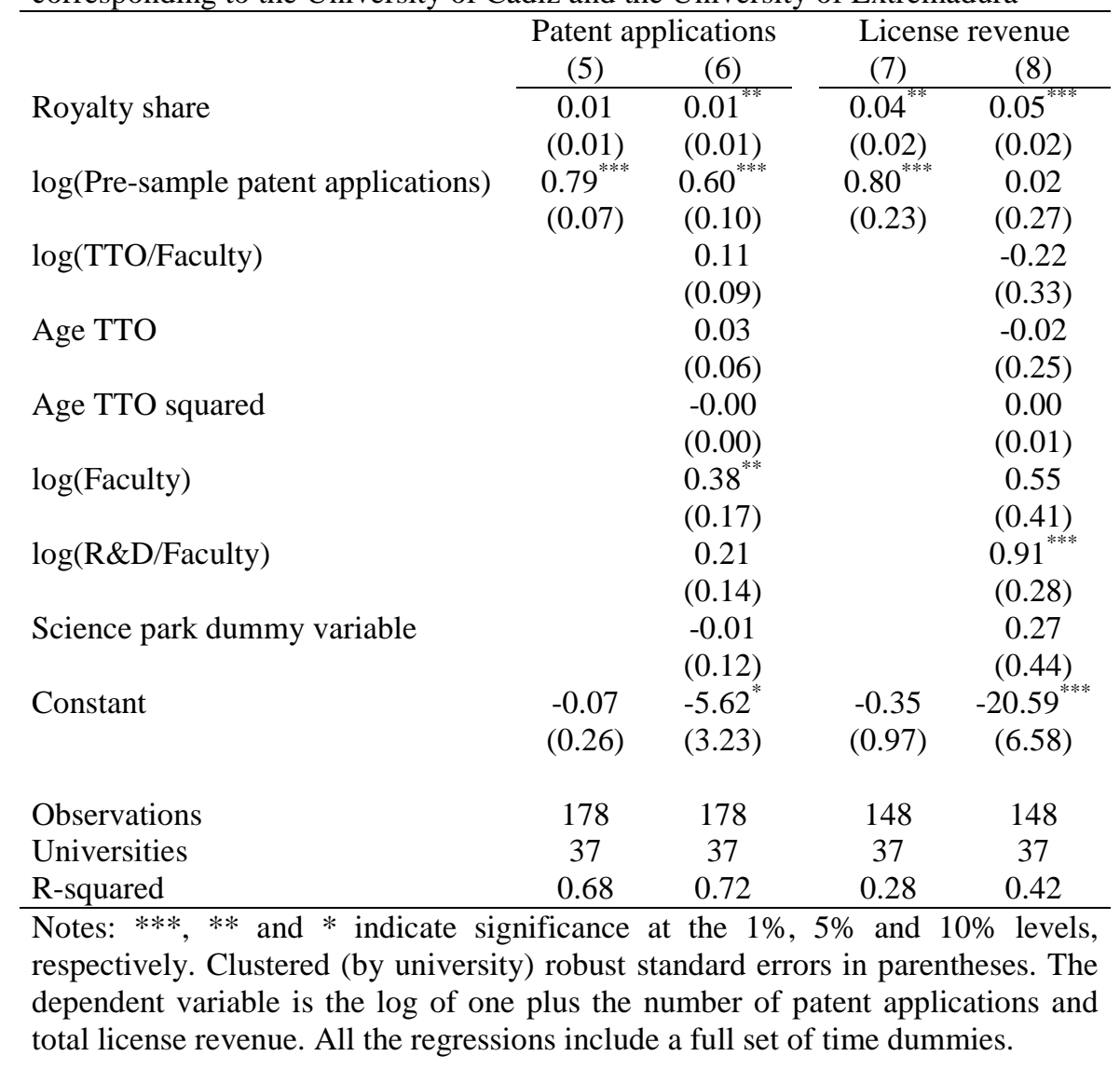

